\title{
Analisis Unit Cost dan Biaya Kepaniteraan Klinik Mahasiswa Profesi Kedokteran Gigi Universitas Udayana dengan Metode Activity Based Costing
}

\author{
Putri Rejeki, ${ }^{1}$ I Gde K. Baskara, ${ }^{2}$ Luh Putu S. Ulandari ${ }^{1 .}$
}

\author{
${ }^{1}$ Program Studi Magister Ilmu Kesehatan Masyarakat Fakultas Kedokteran Universitas \\ Udayana, Bali, Indonesia \\ ${ }^{2}$ Program Studi Magister Manajemen Fakultas Ekonomi dan Bisnis Universitas Udayana, \\ Bali, Indonesia \\ Email: drgputrirejeki@unud.ac.id \\ Disubmisi: 12 Agustus 2021; direvisi: 1 September 2021; diterima 15 September 2021
}

\begin{abstract}
Udayana University (UNUD) School of Dentistry (PSSKGPDG) is one of the dental school in Bali that has problems in analyzing the education cost. Based on previous financial reports, the calculation of the unit cost has been made using the activity based costing (ABC) method for the undergraduate phase. This study was aimed to determine the unit cost and the amount of clinical clerkship education costs that would be proposed using the ABC method. This was a mixed method study using a combination of quantitative and qualitative approaches. The quantitative approach used secondary data of financial statements for the 2019/2020 academic year analyzed by using the ABC method. Meanwhile, the qualitative approach was conducted through in-depth interviews with five informants selected by purposive sampling and then was analyzed thematically. The results showed that the unit cost per semester for PSSKGPDG FK UNUD students was Rp. 61,635,692 which was greater than the unit cost previously calculated by the study program of Rp. 22,319,000. Often the unit costs that had been prepared were not below the budget plan (RAB) due to the lack of detail in budgeting by the study program. In conclusion, although PSSKGPDG prepared RAB by applying the $\mathrm{ABC}$ method, in the end its implementation was not fully realized due to urgent activities or budgets that exceeded the ceiling. Periodic training is needed, therefore, employees can be more thorough and detailed in preparing a budget.
\end{abstract}

Keywords: activity based costing method; unit cost; dentist clinical clerkship

\begin{abstract}
Abstrak: Program Studi Sarjana Kedokteran Gigi dan Profesi Dokter Gigi (PSSKGPDG) Fakultas Kedokteran (FK) Universitas Udayana (UNUD) merupakan salah satu institusi pendidikan dokter gigi di Bali yang memiliki permasalahan dalam analisis biaya pendidikan. Berdasarkan laporan keuangan sebelumnya, perhitungan satuan biaya pendidikan sudah dibuat dengan metode Activity Based Costing (ABC) untuk fase sarjana. Penelitian ini bertujuan untuk mengetahui besaran biaya satuan (unit cost) dan besaran biaya pendidikan kepaniteraan klinik yang akan diusulkan dengan metode ABC. Penelitian ini menggunakan mixed method yaitu kombinasi pendekatan kuantitatif dan kualitatif. Penelitian kuantitatif menggunakan data sekunder laporan keuangan periode tahun ajaran 2019/2020 yang dianalisis menggunakan metode ABC. Penelitian kualitatif dilakukan melalui wawancara mendalam terhadap lima informan yang dipilih secara purposive sampling dan dianalisis secara tematik. Hasil penelitian menunjukkan bahwa unit cost per semester mahasiswa PSSKGPDG FK UNUD sebesar Rp. 61.635.692 yang lebih besar dibandingkan unit cost yang telah dihitung sebelumnya oleh prodi sebesar Rp. 22.319.000. Seringkali unit cost yang telah disusun tidak sesuai dengan rencana anggaran biaya (RAB) dikarenakan kurang detailnya prodi membuat anggaran. Simpulan penelitian ini PSSKGPDG menyusun $\mathrm{RAB}$ dengan menerapkan prinsip $\mathrm{ABC}$, meskipun pada akhirnya dalam penerapannya tidak terealisasikan dengan sempurna karena adanya kegiatan atau anggaran mendesak yang seringkali melebihi pagu. Pelatihan secara berkala sangat diperlukan sehingga pegawai dapat lebih teliti dan detail dalam menyusun suatu anggaran
\end{abstract}

Kata kunci: metode activity based costing; unit cost; kepaniteraan klinik 


\section{PENDAHULUAN}

Kurangnya pemahaman mengenai analisis dan identifikasi aktivitas biaya merupakan salah satu permasalahan yang dihadapi oleh berbagai institusi, salah satunya ialah institusi pendidikan. Selain itu, banyaknya metode yang digunakan untuk mengidentifikasi aktivitas biaya juga merupakan salah satu alasan sulitnya untuk memahami pemakaian biaya di suatu institusi. Metode activity based costing (ABC) merupakan salah satu metode rekomendasi untuk melakukan perhitungan biaya pendidikan. Metode tersebut menghitung biaya berdasarkan kegiatan yang dilakukan untuk mengetahui berapa besaran biaya overhead yang ditimbulkan oleh aktivitas dalam proses pendidikan. ${ }^{1}$

Program Studi Sarjana Kedokteran Gigi dan Profesi Dokter Gigi (PSSKGPDG) Fakultas Kedokteran (FK) Universitas Udayana (UNUD) merupakan salah satu institusi pendidikan dokter gigi di Bali yang memiliki permasalahan dalam analisis biaya pendidikan. Berdasarkan laporan keuangan sebelumnya, perhitungan satuan biaya pendidikan sudah dibuat dengan metode $\mathrm{ABC}$ untuk fase sarjana akan tetapi untuk fase profesi atau kepaniteraan klinik dilakukan menggunakan metode konvensional. Selain itu masalah yang sering terjadi terkait dengan pembiayaan kepaniteraan klinik mahasiswa ialah pihak manajemen Rumah Sakit Perguruan Tinggi Negeri (RSPTN) UNUD seringkali mengeluhkan kurangnya biaya pelaksanaan kepaniteraan klinik dari biaya yang semestinya, sementara pihak FK UNUD seringkali sudah merasa memenuhi jumlah biaya pelaksanaan kepaniteraan klinik. Mahasiswa sebagai pihak yang menanggung biaya pendidikan juga mengeluhkan dan mempertanyakan transparansi dan alokasi biaya yang merupakan hak dan kewajiban mereka, sehingga menimbulkan pertanyaan benarkah biaya yang dikeluarkan oleh para mahasiswa ini dianggap sudah cukup atau masih kurang.

Hasil analisis biaya menggunakan metode $A B C$ ini juga diharapkan dapat dipakai untuk menentukan biaya satuan (unit cost) pelaksanaan pendidikan dokter gigi pada tahap kepaniteraan klinik atau koas. Analisis biaya dengan $\mathrm{ABC}$ ini juga diharapkan bermanfaat untuk program studi dan universitas untuk menentukan secara strategik penerapan biaya secara efektif dan efisien sebagaimana evaluasi yang didapat dari hasil perhitungan biaya sebelumnya. Knowledge gap pada penelitian ini ialah belum adanya penelitian terkait analisis biaya menggunakan metode $\mathrm{ABC}$ di institusi pendidikan dokter gigi di Indonesia, khususnya di Bali.

\section{METODE PENELITIAN}

Penelitian ini menggunakan mixedmethod dengan mengadopsi model eksplanatorik sekuensial. Pengumpulan dan analisis data kuantitatif dilakukan terlebih dahulu menggunakan data sekunder berupa laporan keuangan periode tahun ajaran 2019/2020. Dari laporan tersebut di kumpulkan data meliputi jumlah mahasiswa, jumlah staf pengajar, data aset (gedung dan alat) yang digunakan dalam pendidikan tahap kepaniteraan klinik, biaya operasional (mencakup biaya gaji, honor, alat tulis kantor dan barang cetak, konsumsi), data biaya tidak langsung (mencakup biaya pemeliharan, listrik, air dan unit pendukung). Analisis data kuantitatif dilakukan untuk mengetahui unit cost dengan menggunakan metode ABC.

Data kualitatif diperoleh melalui wawancara mendalam terhadap lima informan yang dipilih secara purposive sampling. Penelitian ini dilakukan terhadap stakeholder yang langsung mengurus bagian administrasi keperluan mahasiswa kepaniteraan klinik. Sebelum dilakukan wawancara, setiap responden diberikan lembar informasi dan bersedia menandatangani informed consent. Analisis data kualitatif dilakukan dengan analisis tematik untuk mengetahui persepsi dari proses penyusunan satuan biaya pendidikan kegiatan kepaniteraan klinik. Penelitian ini memperoleh izin etik dari Komite Etik Fakultas Kedokteran Universitas Udayana/RSUP Sanglah Denpasar dengan nomor keterangan layak etik yaitu No. 2454/UN14.2.2.VII.14/LT/2020.

\section{HASIL PENELITIAN}

Jumlah mahasiswa yang menjalani tahap kepaniteraan klinik pada PSSKGPDG 
FK UNUD pada tahun 2020 sebanyak 156 mahasiswa, terdiri dari 45 mahasiswa angkatan 2017, 44 mahasiswa angkatan 2018, mahasiswa angkatan 2019, dan sebanyak 24 mahasiswa angkatan 2020.

Tabel 1 memperlihatkan rincian jumlah mahasiswa yang menjalani tahap kepaniteraan klinik. Biaya langsung mencakup biaya sarana kuliah, sarana small group discussion (SGD), sarana praktikum, sarana klinik, bahan habis pakai (BHP), kuliah, gedung, serta BHP orientasi dan wisuda.

Tabel 1. Jumlah mahasiswa kedokteran gigi yang menjalani kepaniteraan klinik di Universitas Udayana

\begin{tabular}{cc}
\hline Angkatan & Jumlah mahasiswa \\
\hline 2020 & 24 \\
2019 & 43 \\
2018 & 44 \\
2017 & 45 \\
Total & 156 \\
\hline
\end{tabular}

Tabel 2 memperlihatkan rincian terkait biaya langsung. Komponen biaya langsung terbesar dibebankan pada Semester 12 yaitu sebesar Rp. 1.426.812. Komponen biaya langsung terbesar pada semester 12 disebabkan karena adanya aktivitas yang lebih banyak dibandingkan semester sebelumnya. Aktivitas tersebut di antaranya terdapat Ujian Profesi, UKMP2DG, yudisium, dan wisuda, sehingga terdapat pembebanan biaya langsung yang lebih besar.

Pada penelitian ini, biaya tidak langsung mencakup biaya depresiasi, biaya operasional, biaya pemeliharaan, dan biaya kegiatan lain. Tabel 3 memperlihatkan rincian terkait biaya tidak langsung untuk masing-masing komponen. Biaya operasional terbesar dikeluarkan untuk pengelola dan pegawai yaitu sebesar Rp. 14.728.236.679. Biaya ini digunakan sebagai tunjangan untuk SDM serta biaya lainnya yang tidak terkait pengajaran. SDM dalam hal ini yaitu Koordinator Program Studi (KORPRODI), Ketua Tim Pengendalian Penjaminan Mutu (TPPM), Koordinator Pendidikan (KORDIK) Profesi, dan Ketua Departemen. Di sisi lain, yang dimaksud biaya lainnya yaitu biaya gaji, remunerasi, uang makan, serta insentif pegawai kontrak dan Aparatur Sipil Negara (ASN).

Tabel 4 memperlihatkan keterangan disertai perhitungan terperinci yang memperoleh biaya total secara keseluruhan selama masa kepaniteraan klinik (4 semester) yaitu sebesar Rp. 246.542.766. Komponen biaya total terbesar berasal dari biaya tidak langsung pada Semester 9 yang mencapai Rp. 79.486.954.

Tabel 5 memperlihatkan secara rinci terkait klasifikasi serta jumlah biaya berdasarkan masing-masing cost pool. Biaya cost pool $\mathrm{B}$, diperoleh biaya total cost pool paling tinggi yaitu sebesar Rp. 145.484.781. Biaya pada cost pool ini mencakup biaya kepaniteraan umum sebesar Rp. 30.482.073, biaya penatalaksanaan pasien secara mandiri sebesar Rp. 76.387.282, dan biaya asistensi operator sebesar Rp. 38.615.426.

Dalam menghitung unit cost, dibutuhkan data terkait cost driver. Cost driver dalam penelitian ini yaitu jumlah semester selama masa kepaniteraan klinik pada PSSKGPDG FK UNUD yaitu selama 4 semester yang mencakup Semester 9. Semester 10, Semester 11, dan Semester 12. Selanjutnya, setelah diketahui total biaya dari masing-masing cost pool dan cost driver, maka dilakukan perhitungan unit cost untuk biaya kepaniteraan. Tabel 6 memperlihatkan bahwa berdasarkan perhitungan unit cost diperoleh biaya unit cost untuk kepaniteraan klinik pada PSSKGPDG FK UNUD yaitu sebesar Rp. 61.635.692. Total biaya ini diperoleh dari penjumlahan unit cost per cost driver dari masing-masing cost pool. Untuk cost pool A, yang merupakan unit level activity diperoleh hasil unit cost per cost driver sebesar Rp. 25.072.129. Untuk cost pool B, yang merupakan batch related activity diperoleh hasil unit cost per cost driver sebesar Rp. 36.371.195. Selain itu, untuk cost pool $\mathrm{D}$, yang merupakan facility sustaining diperoleh hasil unit cost per cost driver sebesar Rp192.368. Di sisi lain, tidak diperoleh unit cost per cost driver dari cost pool $C$ dan $E$ karena dalam penelitian ini tidak ditemukan jenis biaya yang masuk ke dalam kategori cost pool $C$ dan $E$. 
Tabel 2. Biaya langsung Kepaniteraan Klinik Kedokteran Gigi Universitas Udayana

\begin{tabular}{|c|c|c|c|c|c|}
\hline \multirow[t]{2}{*}{ No } & \multirow[t]{2}{*}{$\begin{array}{c}\text { Produk } \\
\text { Pelayanan }\end{array}$} & \multirow[t]{2}{*}{$\begin{array}{c}\text { Blok/ } \\
\text { Modul/MK }\end{array}$} & \multirow[t]{2}{*}{ Aktivitas } & \multicolumn{2}{|c|}{$\begin{array}{l}\text { Total Biaya } \\
\text { Langsung }\end{array}$} \\
\hline & & & & Rp. & $(\%)$ \\
\hline \multirow[t]{2}{*}{1} & Penerimaan Koas & Registrasi & Pendaftaran mahasiswa baru & & \\
\hline & & Registrasi ulang & Pengisian KRS & & \\
\hline \multirow[t]{8}{*}{2} & Semester 9 & & Kepaniteraan Umum & 143.541 & $19,86 \%$ \\
\hline & & & Diskusi kasus & 46.581 & $6,45 \%$ \\
\hline & & & Penatalaksanaan pasien secara mandiri & 231.790 & $32,08 \%$ \\
\hline & & & Asistensi operator & 221.341 & $30,63 \%$ \\
\hline & & & Laporan kasus & 10.313 & $1,43 \%$ \\
\hline & & & Peserta seminar & 6.714 & $0,93 \%$ \\
\hline & & & Ujian DOPS & 46.358 & $6,42 \%$ \\
\hline & & & Ujian Minicex & 16.008 & $2,22 \%$ \\
\hline \multicolumn{6}{|c|}{ Total Per Semester 722.647} \\
\hline \multirow[t]{7}{*}{3} & Semester 10 & & Diskusi kasus & 46.581 & $8,04 \%$ \\
\hline & & & Penatalaksanaan pasien secara mandiri & 231.790 & $40,03 \%$ \\
\hline & & & Asistensi operator & 221.341 & $38,22 \%$ \\
\hline & & & Laporan kasus & 10.313 & $1,78 \%$ \\
\hline & & & Peserta seminar & 6.714 & $1,16 \%$ \\
\hline & & & Ujian DOPS & 46.358 & $8,01 \%$ \\
\hline & & & Ujian Minicex & 16.008 & $2,76 \%$ \\
\hline \multicolumn{6}{|c|}{ Total Per Semester 579.106 } \\
\hline \multirow[t]{7}{*}{4} & Semester 11 & & Diskusi kasus & 46.581 & $8,04 \%$ \\
\hline & & & Penatalaksanaan pasien secara mandiri & 231.790 & $40,03 \%$ \\
\hline & & & Asistensi operator & 221.341 & $38,22 \%$ \\
\hline & & & Laporan kasus & 10.313 & $1,78 \%$ \\
\hline & & & Peserta seminar & 6.714 & $1,16 \%$ \\
\hline & & & Ujian DOPS & 46.358 & $8,01 \%$ \\
\hline & & & Ujian Minicex & 16.008 & $2,76 \%$ \\
\hline \multicolumn{6}{|c|}{ Total Per Semester 579.106 } \\
\hline \multirow[t]{14}{*}{5} & Semester 12 & & Diskusi kasus & 46.581 & $3,26 \%$ \\
\hline & & & Penatalaksanaan pasien secara mandiri & 231.790 & $16,25 \%$ \\
\hline & & & Asistensi operator & 221.341 & $15,51 \%$ \\
\hline & & & Laporan kasus & 10.313 & $0,72 \%$ \\
\hline & & & Peserta seminar & 6.714 & $0,47 \%$ \\
\hline & & & Ujian DOPS & 46.358 & $3,25 \%$ \\
\hline & & & Ujian Minicex & 16.008 & $1,12 \%$ \\
\hline & & Ujian profesi & Ujian CBT & 20.863 & $1,46 \%$ \\
\hline & & UKMP2DG & TO UKMP2DG & 28.686 & $2,01 \%$ \\
\hline & & & Ujian & 28.686 & $2,01 \%$ \\
\hline & & Yudisium & Pendaftaran yudisium & 17.950 & $1,26 \%$ \\
\hline & & & Upacara yudisium & 304.388 & $21,33 \%$ \\
\hline & & Wisuda & Pendaftaran wisuda/gladi & 5.983 & $0,42 \%$ \\
\hline & & & Upacara wisuda & 441.150 & $30,92 \%$ \\
\hline
\end{tabular}


Tabel 3. Biaya tidak langsung kepaniteraan klinik kedokteran gigi Universitas Udayana

\begin{tabular}{|c|c|c|c|c|}
\hline No & Komponen Biaya & $\begin{array}{l}\text { Biaya Per } \\
\text { Tahun }\end{array}$ & $\begin{array}{c}\text { Biaya Selama } \\
\text { Kepaniteraan } \\
\text { (4 Semester) }\end{array}$ & $\begin{array}{c}\text { Biaya Per } \\
\text { Mahasiswa/ } \\
\text { Tahun }\end{array}$ \\
\hline \multicolumn{5}{|c|}{ A. $\quad$ Biaya depresiasi } \\
\hline & 1. Depresiasi gedung & 184.345 .000 & & 215.608 \\
\hline & 2. Depresiasi sarana & 168.876 .492 & & 197.516 \\
\hline & 3. Depresiasi rektorat & 272.287 .565 & & 318.465 \\
\hline & Jumlah biaya depresiasi & 625.509 .057 & 1.251 .018 .113 & 731.590 \\
\hline \multirow[t]{5}{*}{ B. } & Biaya operasional & & & \\
\hline & 1. Biaya pengelola dan pegawai & 14.728.236.679 & & 17.226 .008 \\
\hline & $\begin{array}{l}\text { 2. Biaya bahan habis pakai (non } \\
\text { pembelajaran) }\end{array}$ & 19.218 .310 & & 22.478 \\
\hline & 3. Biaya operasional rektorat & 1.182.032.241 & & 1.382 .494 \\
\hline & Jumlah Biaya Operasional & 15.929.487.230 & 31.858 .974 .460 & 18.630 .979 \\
\hline \multirow[t]{4}{*}{ C. } & Biaya pemeliharaan & & & \\
\hline & 1. Biaya pemeliharaan PSPDG & 391.182 .229 & & 457.523 \\
\hline & 2. Biaya pemeliharaan rektorat & 184.948 .491 & & 216.314 \\
\hline & Jumlah Biaya Pemeliharaan & 576.130 .719 & 1.152 .261 .439 & 673.837 \\
\hline \multirow[t]{4}{*}{ D. } & Biaya kegiatan lain & & & \\
\hline & Biaya kegiatan lain PSPDG & 1.334 .126 .000 & & 1.560 .381 \\
\hline & Biaya kegiatan lain Rektorat & 507.084 .465 & & 593.081 \\
\hline & Jumlah biaya kegiatan lain & 1.841.210.465 & 3.682 .420 .930 & 2.153 .463 \\
\hline \multicolumn{2}{|c|}{ Jumlah total biaya tidak langsung } & 18.972.337.471 & & 22.189 .868 \\
\hline \multicolumn{2}{|c|}{$\begin{array}{l}\text { Jumlah total biaya tidak langsung selama } \\
\text { kepaniteraan ( } 4 \text { Semester) }\end{array}$} & 37.944 .674 .943 & 12.648 .224 .981 & 44.379 .737 \\
\hline
\end{tabular}

Tabel 4. Biaya total kepaniteraan klinik kedokteran gigi Universitas Udayana

\begin{tabular}{lcccccc}
\hline \multicolumn{1}{c}{ Kategori } & \multicolumn{2}{c}{ Biaya Langsung } & \multicolumn{2}{c}{ Biaya Tidak langsung } & \multicolumn{2}{c}{ Biaya Total } \\
& Rp. & \% & Rp. & \% & Rp. & \% \\
\hline Semester 9 & 722.647 & $21,85 \%$ & 79.486 .954 & $32,68 \%$ & 80.209 .601 & $32,53 \%$ \\
Semester 10 & 579.106 & $17,51 \%$ & 48.777 .985 & $20,05 \%$ & 49.357 .091 & $20,02 \%$ \\
Semester 11 & 579.106 & $17,51 \%$ & 48.777 .985 & $20,05 \%$ & 49.357 .091 & $20,02 \%$ \\
Semester 12 & 1.426 .812 & $43,14 \%$ & 66.192 .171 & $27,21 \%$ & 67.618 .983 & $27,43 \%$ \\
Total & 3.307 .671 & $100,00 \%$ & 243.235 .095 & $100,00 \%$ & 246.542 .766 & $100,00 \%$ \\
\hline
\end{tabular}

Tabel 5. Total biaya cost pool kepaniteraan klinik mahasiswa Profesi Kedokteran Gigi Fakultas Kedokteran Universitas Udayana

\begin{tabular}{lcc}
\hline \multicolumn{1}{c}{ Jenis Biaya } & Biaya Cost Pool & Total Biaya Cost Pool \\
\hline Cost Pool A & & $\mathbf{1 0 0 . 2 8 8 . 5 1 7}$ \\
Diskusi kasus & 37.916 .386 & \\
Laporan kasus & 15.133 .276 & \\
Peserta seminar & 7.572 .868 & \\
Ujian DOPS & 15.277 .456 & \\
Ujian Minicex & 15.156 .056 & \\
Ujian CBT (Ujian profesi) & 2.133 .379 & \\
Try Out UKMP2DG & 3.549 .548 &
\end{tabular}




\begin{tabular}{lcc}
\hline \multicolumn{1}{c}{ Jenis Biaya } & Biaya Cost Pool & Total Biaya Cost Pool \\
\hline Ujian UKMP2DG & 3.549 .548 & \\
Cost Pool B & & $\mathbf{1 4 5 . 4 8 4 . 7 8 1}$ \\
Kepaniteraan umum & 30.482 .073 & \\
Penatalaksanaan pasien secara & 76.387 .282 & \\
mandiri & 38.615 .426 & \\
Asistensi operator & & $\mathbf{0}$ \\
Cost Pool C & & $\mathbf{7 6 9 . 4 7 1}$ \\
Cost Pool D & 0 & \\
Pendaftaran mahasiswa baru & 0 & \\
(Regustrasi - Penerimaan coass) & 17.950 & \\
Pengisian KRS (Registrasi ulang) & 304.388 & \\
Pendaftaran yudisium & 5.983 & \\
Upacara yudisium & 441.150 & \\
Pendaftaran wisuda/gladi & & \\
Upacara wisuda & & \\
Cost Pool E & & \\
\hline
\end{tabular}

Tabel 6. Perhitungan unit cost kepaniteraan mahasiswa Profesi Kedokteran Gigi Fakultas Kedokteran Universitas Udayana

\begin{tabular}{clrrr}
\hline Cost Pool & \multicolumn{1}{c}{ Keterangan } & Total Biaya & Cost Driver & $\begin{array}{c}\text { Unit Cost Per } \\
\text { Cost Driver }\end{array}$ \\
\hline A & Unit level activity & 100.288 .517 & 4 & 25.072 .129 \\
B & Batch related activity & 145.484 .781 & 4 & 36.371 .195 \\
C & Facility sustaining & 0 & 4 & 0 \\
D & Facility sustaining & 769.471 & 4 & 192.368 \\
E & Unit level activity & 0 & 4 & 0 \\
Unit Cost & & & & $\mathbf{6 1 . 6 3 5 . 6 9 2}$ \\
\hline
\end{tabular}

Pada penelitian ini, data kualitatif didapatkan melalui wawancara pada tiga orang pemegang kebijakan dan dua orang konsumen (mahasiswa dan orangtua mahasiswa PSPDG. Informan yang dipilih berdasarkan kebutuhan yang berhubungan dengan kebijakan terkait administrasi di PSSKGPDG FK UNUD dan mahasiswa sebagai konsumen di program studi tersebut.

\section{Manajemen Keuangan PSSKGPDG di FK UNUD}

Hasil penelitian ini menjelaskan bahwa, manajemen keuangan PSSKGPDG masih dibawahi oleh fakultas secara penuh. Dalam menetapkan suatu kegiatan, PSSKGPDG dan prodi lainnya diharuskan untuk membuat Petunjuk Operasional Kegiatan (POK) sebagai dasar penyusunan Rancangan Ang- garan Biaya (RAB). Hal tersebut diungkap informan sebagai berikut:

"Yang jelas kalau mekanisme keuangan, pertama mereka mengajukan usulannya dari masing-masing prodi. Itu biasanya jangka waktu setahun atau dua tahun sebelumnya mereka membuat rencana kerja namanya. Di rencana kerja dibuat dua tahun, jadi di satu tahun sebelumnya biasanya sebelum dilaksanakannya POK tahun berjalan itu diadakan musrenbang. Musyawarah yang semua prodi diundang disana membicarakan prodi. Sebelum itu dibicarakan, di tingkat pimpinan tentunya akan dikoordinasikan terlebih dulu dipanggil Kaprodinya berapa mereka rencanakan untuk proses setelah nanti terjadi POK itu." (I1)

Dalam penyusunan POK, keterlibatan pejabat sepeti Dekan, Wakil Dekan, dan 
semua koordinator Program Studi Fakultas Kedokteran sangatlah penting untuk mendapatkan kesepakatan yang bersifat mutlak. Setelah adanya POK yang disetujui baik di tingkat fakultas maupun universitas, kewajiban prodi akan berlanjut ketahap pembuatan RAB yang sesuai dengan POK yang telah disetujui. Hal tersebut diungkap informan sebagai berikut:

"Jadi keuangan itu sebenarnya ber-asal dari usulan masing-masing unit prodi. Jadi mereka yang merencanakan apa yang akan dilakukan, apa yang akan istilahnya dilakukan di tahun berjalan setelah POK itu terbit. Tapi kalau di DIPA sebenarnya itu sudah terbit di Bulan Desember, umpamanya terbit di tahun 2021, tahun 2020 sudah ada DIPAnya di Kementerian tapi eksekusinya tetap menunggu keputusan Rektor. Sehingga pra DIPA istilahnya kalau kami kegiatan yang berjalan di Bulan Januari itu biasanya memakai pra DIPA, tapi mereka sudah punya POK." (I1)

Dalam penyusunan POK, kajian-kajian telah dilakukan sebelum POK tersebut disetujui. Namun, jika terjadi perubahan anggaran sangat perlu penyesuaian kembali sampai pada level kementerian. Dalam penyesuaian tersebut, rapat Musyawarah Rencana Pembangunan (Musrenbang) juga akan diadakan kembali oleh pimpinan untuk mesosialisasikan POK yang telah dikaji.

Selama pendidikan kepaniteraan klinik dilaksanakan mahasiswa di Rumah Sakit Perguruan Tinggi Negeri (RSPTN), prodi memiliki peran dalam menyusun anggaran yang diperlukan oleh mahasiswa selama pendidikan. Setelah disusun, proses pengesahan pun dilakukan oleh koordinator prodi untuk dapat dilaporkan ke pimpinan fakultas untuk nantinya dapat melakukan pembayaran ke wahana sesuai dengan anggaran yang telah disahkan.

"Iya. Jadi kalau koordik profesi itu sebenarnya sebagai verifikator requirement koas itu apakah benar sekian banyaknya. Jadi mereka selama 2 tahun, perhitungan kita kan selama 2 tahun ya, jadi anggapan 2 tahun itu lulus. Jadi koordik profesi itu sebagai verifikator. Kemudian setelah itu kita susun perhitungannya. Nah kalau untuk koor prodi itu mengetahui apa yang sudah kita susun. Jadi beliau mengesahkan apa yang sudah kita susun dan dilaporkan ke pimpinan di fakultas. Biasanya sih kita laporkan ke Wadek II apa yang akan kita bayarkan ke Rumah Sakit UNUD sebagai wahana, jadi apa yang akan kita belanja atau pengeluaran apa yang akan kita keluarkan itu kita laporkan ke Wadek II." (I2)

\section{Mekanisme Pengadaan dan Pencairan dana di PSSKGPDG FK UNUD}

Dalam proses pengadaan, baik fakultas maupun universitas memiliki standar operasional prosedur yang harus diikuti guna memperlancar pencairan dana yang telah dianggarkan. Pencairan dana pada tingkat universitas dilakukan sebanyak empat kali atau setiap triwulan. Untuk memperlancar pencairan pada triwulan berikutnya, sangat perlu untuk melaporkan pertanggungjawaban penggunaan anggaran pada periode sebelumnya. Hal tersebut diungkap informan sebagai berikut.

"Dalam satu tahun anggaran itu sebenarnya kegiatan kita dibagi menjadi 4 tahap keuangan. Jadi kita sudah punya target nih, di tahap I kegiatan apa yang akan kita lakukan, di tahap II apa dan di tahap III, IV itu apa yang akan kita lakukan berkaitan dengan capaian." (I2)

"Pencairan dana kalau di universitas sih 4 kali ya jadi triwulanan dia istilahnya. Cuma kami itu aturannya dari sisi keuangan itu kan ada UP istilahnya kalau itu tidak tercapai 50\% maka kami tidak bisa klaim ke pusat. Jadi sebenarnya pencairan dana kalau itu sudah klop $100 \%$ maka hari itu juga sudah bisa dilakukan pencairan. Tapi kalau belum klop dia istilahnya, itu kita punya uang muka 1 juta. Jadi setengahnya harus terpenuhi dulu surat pertanggungjawaban (SPJ) itu, baru bisa disampaikan ke pusat." (I1)

Jika pertanggungjawaban masih di bawah 50\%, pihak fakultas harus menunggu SPJ yang lain sehingga hal inilah yang seringkali menunda pencairan dana tersebut. Hal ini sebenarnya terkait keaktifan di masing-masing user yang menggunakan dana. Kendala yang terjadi ialah ketika telah mendapat uang muka, harus segera disele- 
saikan pertanggungjawaban kegiatan yang sudah berlangsung.

"Nah ini kaitannya bukan hanya satu prodi, umpamanya prodi gigi lengkap nih sudah $100 \%$ tapi prodi yang lain belum, jadi itu yang menghambat. Jadi kami gak bisa...Nunggu semua karena kan kami harus mencapai $50 \%$ itu baru bisa bawa ke bukit. Karena crosscheck nya itu dilihat di rekeningnya. Kalau rekening itu sudah $50 \%$ kosong baru bisa lagi cair." (I1)

Pada sisi lain, sebagai fakultas yang memiliki beberapa program studi, yang dimana proses pencairan akan sangat terhambat jika ada salah satu saja dari program studi yang tidak tepat waktu dalam mempertanggungjawabkan penggunaan anggarannya.

"Sebenarnya yang mengeluh itu bukan dari prodinya, dari kami malah yang mengeluh. Karena kan basis mereka kerja kan uang mereka ikut. Hanya saja kami yang di tingkat keuangan ini yang istilahnya "tolong dong uangnya sudah kamu ambil, udah kamu pake jadi SPJnya cepet dong" gitu sebenarnya. Jadi kalau ada dana kurang itu gak mungkin, karena kan basis kerjanya POK itu sendiri. Nah kendalanya itu sekarang kan ada surat pesanan yang baru itu, jadi mereka harus memenuhi Berita Acara Serah Terima (BAST), barang yang diterima dengan lengkap, ada Berita Acara Pemberian Penjelasan Pekerjaan (BAPP) itu harus dipenuhi. Kalau mengeluh itu kami yang mengeluh sebenarnya kalau cepet sih kami akan cepet juga dari sisi keuangan." (I1)

Penelitian ini menjelaskan secara terperinci apa saja kendala yang dihadapi oleh tingkat fakultas maupun prodi dalam mencairkan anggaran untuk periode selanjutnya.

\section{Pengelolaan Alokasi Dana Uang Kuliah Tunggal di PSSKGPDG FK UNUD}

Uang Kuliah Tunggal (UKT) mahasiswa akan dialokasikan ke prodi sesuai dengan kebutuhan yang telah direncanakan dengan prinsip ABC. Biaya UKT yang selama ini ditetapkan pun bukan hanya untuk biaya pendidikan mahasiswa namun juga secara manajemen juga difasilitasi dari UKT. Hal tersebut diungkap informan sebagai berikut.
"Jangankan di profesi, kalau di sarjana saja itu menurut saya kurang karena kan seharusnya ada activity based cost yang kita buat kemudian itu yang kita laporkan maka itu yang akan kita terima kan gitu seharusnya." (I2)

Mengacu pada tujuan UKT yang diperuntukkan untuk mahasiswa selama masa pendidikan saja. Namun jika semua dibebankan kepada mahasiswa, hal ini akan sangat berat, karena UKT bukan hanya untuk kepentingan di sisi operasional mahasiswa saja tapi juga di sisi manajemen yang harus difasilitasi dari beban UKT itu sendiri.

“..jadi UKT itu kan gak sepenuhnya diterima oleh prodi, sehingga dari universitas itu dipotong untuk turun ke fakultas dulu, baru dari fakultas itu dipotong lagi untuk turun ke prodi. Jadi prodi itu sudah mendapatkan oh dana yang bisa dihabiskan oleh prodi itu sekian." (I2)

Uang Kuliah Tunggal (UKT) disusun berdasarkan berapa yang dihabiskan oleh mahasiswa dalam satu hari termasuk gaji pegawai dan fasilitas-fasilitas yang digunakan selama pendidikan di kampus. PSSKG PDG di bawah FK tidak menerima 100\% UKT mahasiswa, sumber biaya operasional baik untuk mahasiswa maupun dosen pun hanya berasal dari UKT dan tidak ada sumber pembiayaan lain untuk memenuhi operasional prodi PSPDG FK UNUD.

"Nah ini, seharusnya kita punya tuh slot uang untuk kegiatan tidak terduga. Kalau menurut saya nih pribadi, harusnya ada dua prodi di sini yaitu prodi sarjana dan prodi profesi. Seharusnya keuangannya terpisah tidak digabung. Sementara ini terjadi kan karena kita berada di bawah naungan satu prodi ya keuangannya ini bergabung dan berupa dana bantuan ke profesi. Jadi profesi ini belum punya dana maksudnya nominal kamu sekian saya turunkan dari UKT itu belum ada. Jadi itu sebenarnya yang kita harapkan sih seperti itu karena profesi bisa lebih banyak dananya seharusnya. " (I2)

Pada sisi lain, permasalahan yang sama juga diungkap informan, dimana UKT perlu dialokasikan untuk pembentukan dana darurat.

Jadinya kan memudahkan di orang 
prodinya juga untuk mengatur keuangannya ya. Jadi sebenarnya kita kalau sudah ada dana bantuan profesi itu tidak perlu lagi apaapa lapor ke fakultas dan apa-apa lapor ke rumah sakit. Sebenarnya kita kalau mau ada dana maintenance, itu sebenarnya bisa ambil dana disitu." (I2)

Pernyataan informan terkait pemecahan manajemen untuk sarjana dan profesi pun didukung oleh informan 2 yang mengatakan bahwa hal tersebut akan sangat memudahkan prodi dalam mengatur alur keuangannya.

\section{Monitoring dan Evaluasi Penggunaan Dana di PSSKGPDG FK UNUD}

Dalam melakukan rapat rutin, evaluasi terhadap capaian kegiatan selalu dibahas dan disampaikan. Hal tersebut untuk mengetahui apakah dana yang dianggarkan sudah terserap atau belum. Namun, informan mengatakan bahwa evaluasi terhadap serapan dana dilakukan agar kendala-kendala yang dihadapi dibahas untuk bersama-sama mencari solusinya. Hal tersebut diungkap informan sebagai berikut.

“..Kan pimpinan juga sudah melakukan itu setiap rapat pimpinan yang setiap bulan dilaksanakan pasti akan disampaikan capaian, serapan dan sebagainya itu disampaikan pada rapat itu. Kalau serapan biasanya bisa dilihat sih di aplikasi SIAKUnya mereka untuk berapa persen sih mereka serapannya, itu di aplikasi ada itu TWI tercapai atau tidak kemudian TW2 itu tercapai atau tidak itu keliatan persentase-nya. Kalau penyampaian serapannya di rapim itu setahun dua kali. Itu setiap saat pun bisa dilakukan oleh pimpinan karena itu basisnya basis aplikasi jadi pimpinan sudah bisa melakukan monev by system semua. Di sisi perencanaan juga setiap triwulan akan dilakukan. Jadi yang pokok yaitu setiap triwulan, jadi TWI berjalan pasti akan dilakukan monev." (I1)

Monitoring dan evaluasi yang dilakukan setiap kuartal sangat perlu dilakukan, tidak menutup kemungkinan bahwa kendala maupun perubahan akan selalu ada. Serapan dana menjadi salah satu point yang terus akan dibahas di dalam kegiatan monitoring evaluasi.

Jadi belanja mana yang belum, apa yang menjadi kendala, itu yang akan disampaikan langsung ke pimpinan. Jadi pada rapim itu koordinatornya pasti akan ditanya apa yang menjadi hambatan dan kenapa serapannya seperti ini, kemudian ada perubahan atau tidak. Kalau ada perubahan akan disampaikan disitu. Jadi TW1 berjalan ada monev, TW2 berjalan ada monev dan begitu seterusnya. Jadi bisa dibilang monevnya ada 4 kali setiap tahunnya karena setiap tahun pimpinan harus buat laporan kinerja yang sekarang lagi dikejar." (I1)

Monitoring dan evaluasi setiap kuartal sangat perlu dilakukan, tidak menutup kemungkinan bahwa kendala maupun perubahan akan selalu ada. Fungsi dari monitoring dan evaluasi ini akan sangat berguna untuk kelanjutan kegiatan-kegiatan yang akan dikerjakan. Selain itu, monitoring dan evalusi dilakukan secara rutin karena nantinya juga akan berkaitan dengan laporan kinerja yang harus disusun setiap tahun.

\section{BAHASAN}

Komponen biaya langsung terbesar dibebankan pada Semester 12 yaitu sebesar Rp. 1.426.812,00. Komponen biaya langsung terbesar pada semester 12 disebabkan karena adanya aktivitas yang lebih banyak dibandingkan semester sebelumnya. Aktivitas tersebut di antaranya terdapat ujian profesi, UKMP2DG, yudisium, dan wisuda sehingga terdapat pembebanan biaya langsung yang lebih besar. Hal tersebut didukung oleh penelitian yang dilakukan di FK Universitas Indonesia tahun 2008 yang menjelaskan bahwa biaya total semester 1112 lebih besar hampir tiga kali lipat dari semester 7-8. Hal ini disebabkan karena aktivitas pada semester 11-12 lebih kompleks dan lebih banyak dibandingkan semester sebelumnya. ${ }^{2}$ Horngren et $\mathrm{al}^{3}$ menjelaskan bahwa pemicu biaya ialah variabel seperti aktivitas yang berhubungan sebab akibat dengan perubahan biaya total. Oleh karena jumlah waktu kuliah semakin bertambah banyak maka biaya atas sumber daya seperti sarana kuliah, sarana SGD, sarana praktikum, sarana klinik, serta BHP kuliah dan gedung akan semakin besar

Komponen biaya tidak langsung terbe- 
sar bersumber dari biaya operasional yaitu sebesar Rp. 15.929.487.230 tiap tahunnya. Biaya operasional terbesar dikeluarkan untuk pengelola dan pegawai yaitu sebesar Rp. 14.728.236.679. Biaya ini digunakan untuk tunjangan SDM serta biaya lainnya yang tidak terkait pengajaran. SDM dalam hal ini yaitu KORPRODI, Ketua TPPM, KORDIK Profesi, Ketua Departemen. Di sisi lain, yang dimaksud biaya lainnya yaitu biaya gaji, remunerasi, uang makan, dan insentif pegawai kontrak serta PNS. Berbeda halnya dengan penelitian di Universitas Negeri Yogyakarta yang menyatakan bahwa biaya tidak langsung yang dikeluarkan sebesar Rp. 5.572.067.868. Hal tersebut terjadi karena penelitian dilakukan pada mahasiswa akuntasi yang sangat memerlukan kerjasama dengan banyak instansi serta dukungan fasilitas kampus untuk memudahkan proses perkuliahan. ${ }^{4}$

Nilai unit cost per semester sebesar Rp. 61.635.692. Biaya kuliah tunggal (BKT) yang sudah dihitung oleh prodi dan disetujui pihak kementerian pada tahun ajaran sebelumnya tercatat sebesar Rp. 22.319.000 per semester. Berdasarkan data tersebut, dapat disimpulkan bahwa unit cost untuk mahasiswa per semester lebih besar dibandingkan dengan BKT yang dibayarkan oleh mahasiswa tiap semesternya. Hasil perhitungan unit cost biaya kepaniteraan klinik yang dilakukan di FK Unissula memperoleh total unit cost sebesar Rp. 1.004.766,44. Hasil perhitungan ini lebih besar $(5,7 \%)$ daripada biaya kepaniteraan klinik yang telah ditetapkan, ${ }^{5}$ namun biaya tersebut lebih kecil bila dibandingkan dengan hasil penelitian ini.

Besaran UKT telah disusun berdasarkan kebutuhan mahasiswa, sehingga tinggi rendahnya UKT tergantung dari kebutuhan mahasiswa pada prodi tersebut. Pada PSSKGPDG UNUD, usulan pembiayaan yang telah disetujui merupakan akumulasi dari tingkat sarjana dan profesi. Oleh karena itu perlu ketelitian dalam memecah POK dalam pembuatan RAB. Hal tersebut didukung oleh penelitian FK Unissula yang menyebutkan bahwa perlunya penghitungan anggaran secara rinci, hanya dihitung biaya- biaya yang secara jelas terkait dengan kepaniteraan klinik. Perhitungan belum sepenuhnya mencerminkan biaya riil kepaniteraan klinik, karena penentuan lebih bersifat perkiraan dan melihat FK swasta yang lain. ${ }^{5}$

Dalam penyusunan suatu anggaran sangat diperlukan ketelitian dan detail sehingga ke depannya tidak ada hambatan dalam penggunaan anggaran. Namun pada sisi lain, penelitian ini juga melihat bahwa sebenarnya ada prinsip fleksibilitas, dimana informan mengatakan bahwa dalam kasus urgensi, universitas akan mempertimbangkan untuk penyediaan anggaran yang diperuntukkan bagi hal yang sangat mendesak. ${ }^{6}$

Dalam penelitian ini, temuan yang paling sering terjadi yaitu adanya kebocoran dana di klinik profesi. Hal ini dikarenakan tidak terduganya kerusakan yang terjadi pada alat-alat medis yang digunakan. Dalam kasus kebocoran dana ini, seringkali kerusakan yang tidak terduga terjadi dan sangat sulit mencari anggaran dikarenakan sudah melebih pagu anggaran. Solusi yang diambil pun mengarah pada pimpinan tertinggi di Rektorat UNUD.

Kegiatan monitoring dan evaluasi sangat perlu dilakukan setiap kuartal, dan tidak menutup kemungkinan bahwa kendala maupun perubahan akan selalu ada. Oleh karena itu fungsi monitoring dan evaluasi ini sangat berguna untuk kelanjutan kegiatan yang akan dikerjakan. Selain itu, monitoring dan evaluasi dilakukan secara rutin karena nantinya juga akan berkaitan dengan laporan kinerja yang harus disusun setiap tahun.

\section{SIMPULAN}

Unit cost per semester mahasiswa PSSKGPDG FK UNUD sebesar Rp. 61.635.692. Hasil tersebut lebih besar dibandingkan dengan unit cost yang telah dihitung pada tahun ajaran sebelumnya sebesar Rp. 22.319.000. Walaupun PSSKGPDG menyusun RAB dengan menerapkan prinsip $\mathrm{ABC}$, namun pada akhirnya tidak terealisasikan dengan sempurna karena adanya kegiatan atau anggaran mendesak yang seringkali melebihi pagu. Pelatihan secara berkala sangat 
diperlukan sehingga pegawai dapat lebih teliti dan detail dalam menyusun suatu anggaran.

\section{Konflik Kepentingan}

Penulis menyatakan tidak terdapat konflik kepentingan dalam penelitian ini.

\section{DAFTAR PUSTAKA}

1. Yuni, Matrutty TJF., Sipakoly S. Penerapan metode activity based costing dalam menentukan tarif SPP Pogram Studi Diploma IV Administrasi Bisnis Terapan Poliklinik Negeri Ambon. Maneksi. 2018;4(2):35-55. Available from: https://doi.org/10.31959/jm.v4i2. 161.g76.

2. Dewi AS. Analisis biaya pendidikan dokter FKUI Tahap Kepaniteraan Klinik di Departemen Obstetri dan Ginekologi RSCM Jakarta Tahun 2007 [Tesis].
Jakarta: Universitas Indonesia; 2008.

3. Horngren CT, Foster G, Datar SM, Rajan M, Ittner C, Baldwin AA. Cost Accounting: A Managerial Emphasis, Vol. 25, Issues in Accounting Education. 2010. 789-90 p.

4. Handayani CT, Sukirno. Analisis perhitungan biaya satuan (unit cost) di Fakultas Ekonomi Universitas Negeri Yogyakarta. J Kaji Pendidik Akunt Indones. 2016;I:1-12.

5. Masyhudi. Analisis biaya dengan metode activity based costing Unissula di Rumah Sakit Pendidikan (Studi kasus di Rumah Sakit Islam Sultan Agung) [Tesis]. Semarang: Universitas Diponegoro; 2008

6. Prihatin SD, Daryanti S, Pramadha RA. Aplikasi Teori Perencanaan: dari Konsep ke Realita. Yogyakarta: CV. Buana Grafika, 2019; p. 99-117. 